D. KALJO, Nelli BOROVKO, Heljo HEINSALU, K. KHAZANOVICH, Kaisa MENS, L. POPOV, S. SERGEYEVA, R. SOBOLEVSKAYA, Viive VIIRA

\title{
THE CAMBRIAN-ORDOVICIAN BOUNDARY IN THE BALTIC-LADOGA CLINT AREA (NORTH ESTONIA AND LENINGRAD REGION, USSR)
}

The Baltic-Ladoga clint area extends over the whole of northern Estonia and the Leningrad Region, from the Pakri Islands in the west as far as Lake Ladoga in the east (Fig. 1). The numerous good outcrops (sections) enabling detailed studies of the structure of the boundary beds (Fig. 2) are situated on the clint and in the river valleys crossing it. Seven of these sections are figured and discussed below (Fig. 3), although, of course, all others are also taken into consideration in the discussion.

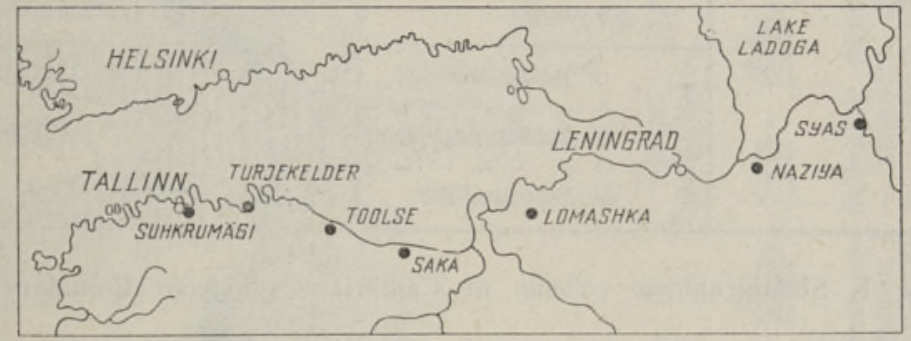

Fig. 1. Location map showing sections (black points) given in Fig. 3.

As a general rule in the East Baltic, the Cambrian-Ordovician Boundary has been drawn at the base of the so-called Obolus Sandstone which overlies Cambrian arenites of different ages; this is the base of the Pakerort Regional Stage, taken as an equivalent of the Lower Tremadoc in Great Britain and Scandinavia. Such a correlation was motivated mostly by finds of different species and subspecies of the Dictyonema (= Rhabdinopora) flabelliforme (Eichwald) group of graptolites from the so-called Dictyonema Shale constituting the upper part of the Pakerort Regional Stage, as well as from shale interbeds in the Obolus Sandstone (in some sections, e. g. Kalvi and Aseri, from almost the lowermost beds). The established graptolite succession shows the presence of deposits through an interval from the D. sociale Subzone up to the Upper Tremadoc Clonograptus-Didymograptus Zone (Кальо, Кивимяги, 1970, 1976).

Data obtained recently on the micropaleontology of Cambrian-Ordovician strata (Боровко, Сергеева, 1981; Волкова, 1980; Хазанович и др., 1984) have established a problem in attributing a part of the Obolus Sandstone to the Cambrian. In $1952 \mathrm{~A}$. Opik already regarded the 
lowermost beds of the Pakerort Regional Stage, the Acrotreta Zone (now called the Olgase Formation), as Upper Cambrian. Results of lithological investigations of the East Baltic sections (N. Borovko, H. Heinsalu, K. Khazanovich, K. Mens) together with data on brachiopods (L. Popov), conodonts (V. Viira, S. Sergeyeva) and graptolites (D. Kaljo, R. Sobolevskaya) are also significant in contributing to the solution of the general problem of the Cambrian-Ordovician Boundary, which is now under discussion in a corresponding IUGS working group. Accordingly, the main subjects of this paper are the succession of conodont zones and their relations with graptolite zones, together with a concrete definition of this boundary in the sections of the study area.

\begin{tabular}{|c|c|c|c|c|c|}
\hline Graptolite zones & Conodont zones & \multicolumn{2}{|c|}{ FORMATIONS } & Regio- \\
stages
\end{tabular}

Table 1. Stratigraphical scheme of Cambrian-Ordovician Boundary beds.

A general stratigraphical scheme is given in Table 1 , and relations between the formations distinguished along the clint line are shown in Fig. 2. Brief characteristics of the sections are given below.

\section{Lithology and lithostratigraphy}

The Pakerort Regional Stage is underlain by an entirely terrigenous sequence of different-aged Cambrian rocks, revealing the recurrent and complicated nature of sedimentation and denudation processes.

Tiskre Formation (Lower Cambrian). This division is represented mainly by oligomineralic sandy siltstones; it crops out in Estonia and at Koporye High in the Leningrad Region (Fig. 2) (see Менс, Пирpyc, 1977). Denudation has reached down to the Lükati Formation (Schmidtiellus mickwitzi Zone) only at the centre of this dome structure.

Sablinka Formation (Middle Cambrian). The mature silty sandstones of this formation crop out mostly in the western part of the Leningrad Region where they form the top of the pre-Ordovician rocks. On the basis of scarce finds of inarticulate brachiopods, bradoriids and acritarchs, the beds are assigned conditionally to the Paradoxides paradoxissimus and $\mathrm{P}$. forchhammeri Zones. 


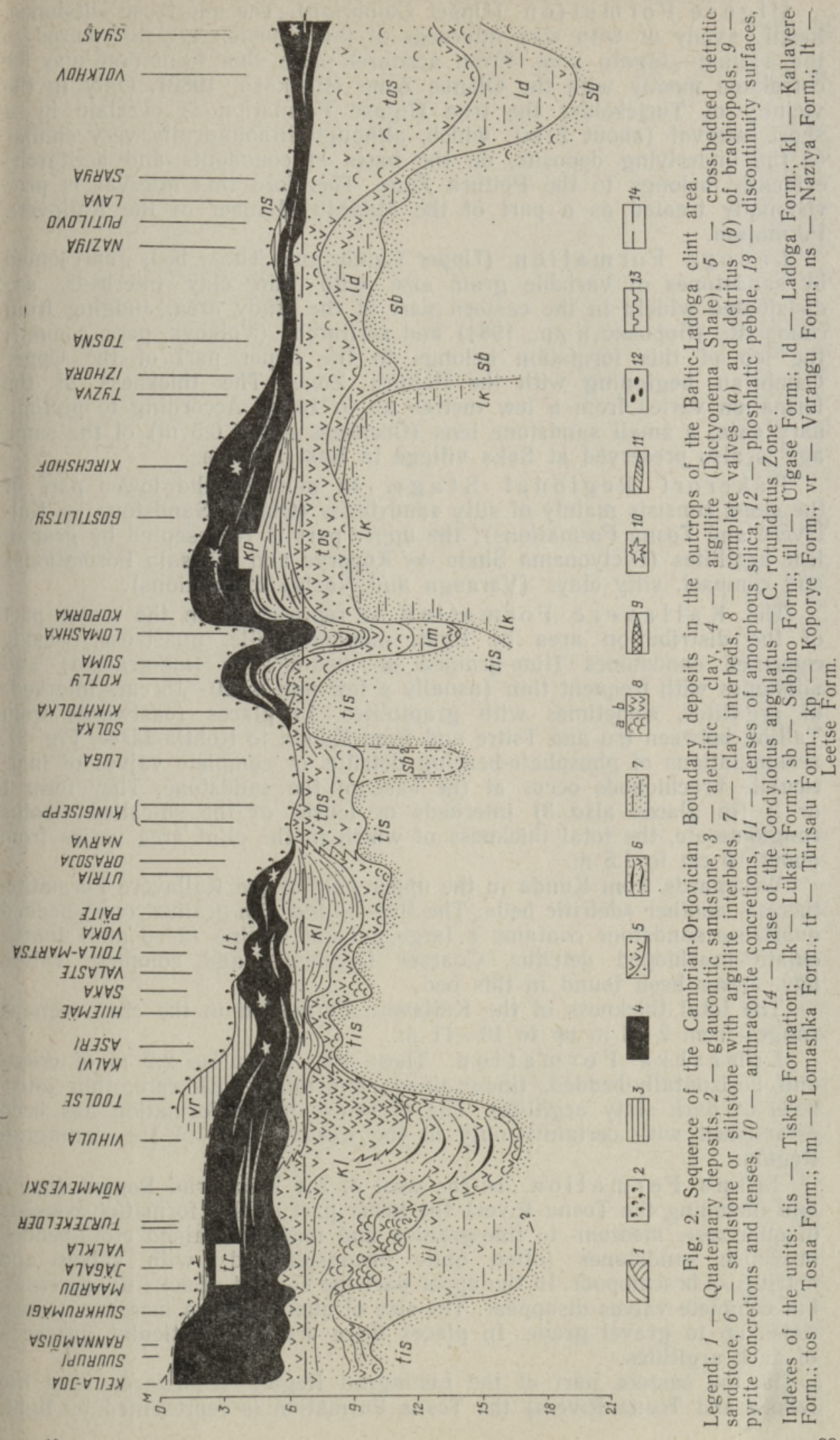


Ulgase Formation (Upper Cambrian). The quartzose siltstones, locally sandy or with clay interbeds of this division are distributed in the Tallinn-Jägala area. From acritarch data this formation may be correlated mostly with the Olenus Zone (Волкова, 1982). Only in the vicinity of Turjekelder the true Ulgase Formation is overlain by a short interval (about $2 \mathrm{~m}$ ), which, although lithologically very similar to the underlying deposits, on the basis of conodonts and acritarchs evidently belongs to the Peltura Zone. Therefore this interval is provisionally treated as a part of the Maardu Member of the Kallavere Formation.

Ladoga Formation (Upper Cambrian). These beds represented by sandstones of variable grain size with thin clay interbeds, are distributed widely in the eastern part of the study area. Judging from conodonts (Боровко и др., 1984) and acritarchs (Volkova, pers. comm.), the top of this formation belongs to the upper part of the Upper Cambrian, beginning with the Peltura Zone. The thickness of the formation varies from a few metres up to $10 \mathrm{~m}$. According to preliminary data, a small sandstone lens (thickness about $0.5 \mathrm{~m}$ ) of the same age is also preserved at Saka village in East Estonia.

Pakerort Regional Stage. In general, the lower part of the stage consists mainly of silty sandstones (Obolus Sandstone $=\mathrm{Kal}$ lavere and Tosna Formations); the upper part is represented by graptolitic argillites (Dictyonema Shale $=$ Koporye and Türisalu Formations) and compact, silty clays (Varangu and Naziya Formations).

The Kallavere Formation is represented in the major part of the distribution area by light, monomineralic, quartzose, weakly cemented sandstones (fine-grained or medium- to fine-grained) and siltstones with frequent thin (usually a few $\mathrm{mm}$ to $10-15 \mathrm{~cm}$ ) interbeds of argillites, sometimes with graptolites. In places (eastwards from Tallinn between Iru and Tsitre and from Kunda to Kohtla-Järve, Fig. 2), accumulations of phosphate-bearing detritus or complete valves of inarticulate brachiopods occur at the base of the sandstone. They form 1 or 2 (in places also 3) interbeds or lenses of the so-called Obolus conglomerate, the total thickness of which in the clint area varies from about $10 \mathrm{~cm}$ to $1.5 \mathrm{~m}$.

Westwards from Kunda in the upper part of the Kallavere Formation there is another «detritic bed». The fine- to medium-grained cross-bedded quartzose sandstone contains a large amount of fine $(2-3 \mathrm{~mm})$ inarticulate brachiopod detritus. Coarser fragments and complete valves have never been found in this bed.

The total thickness of the Kallavere Formation in the clint sections ranges from $2-3 \mathrm{~m}$ up to $10-11 \mathrm{~m}$.

Lomashka Formation. These beds comprise $2.2 \mathrm{~m}$ of crossand horizontally-bedded, fine-grained sandstones with rare, thin interbeds of dark slaty argillites. The presence of the formation has been established with certainty only in the western part of the Leningrad Region.

Tosna Formation. In the west of the Leningrad Region (up to and including the Tosna River) the lower part of this formation consists of quartzose, medium- to fine-grained and medium-grained cross-bedded brownish sandstones (often quite unconsolidated) with valves and detritus of brachiopods. In the upper part the content of detritus increases, but complete valves disappear. The size of quartz grains increases, sometimes up to gravel grade. In places there are rare lenticular interbeds of dark argillites.

In the eastern part of the Leningrad Region (eastwards from the Izhora and Tosna Rivers) the Tosna Formation is represented by light, 


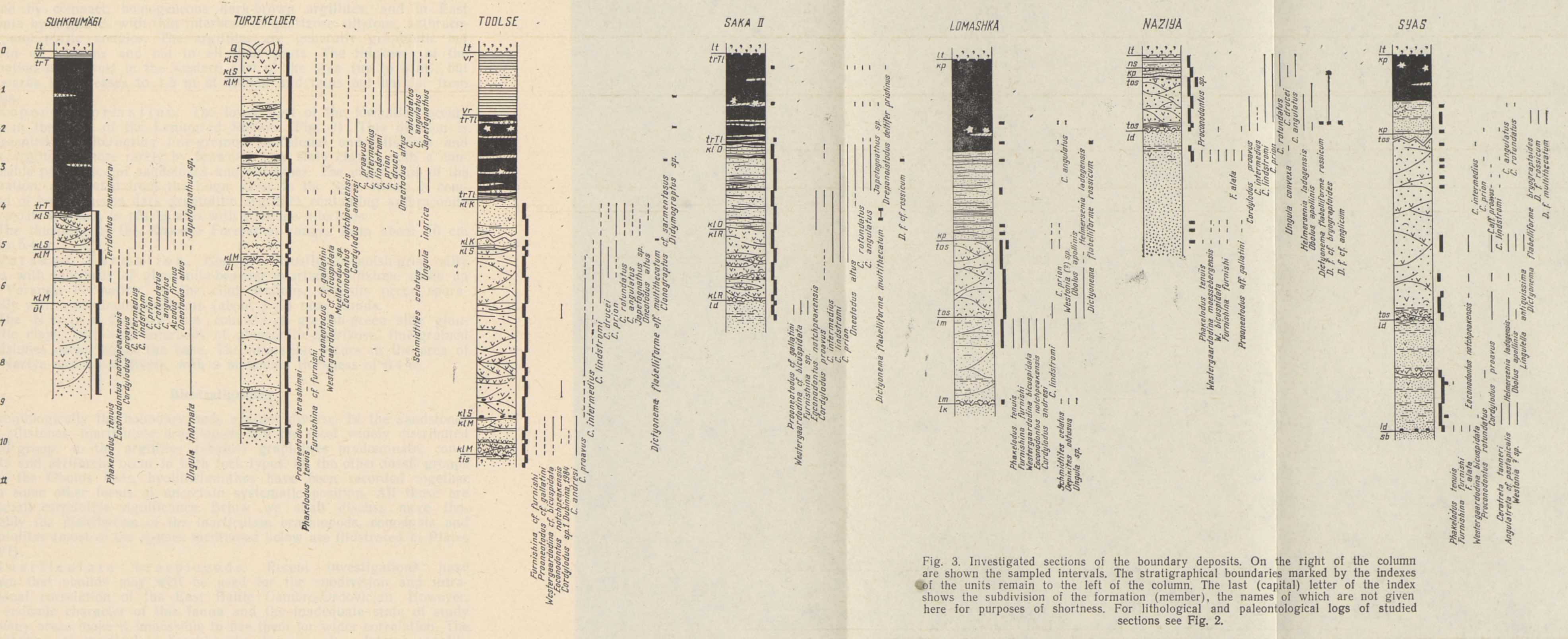


fine-grained, weakly cemented sandstones with a lesser amount of detritus or complete brachiopod valves.

The total thickness of the Tosna Formation ranges from 0.5 to $7.5 \mathrm{~m}$, increasing eastwards.

$\mathrm{Tür}$ isalu Formation. In West Estonia this formation is represented by compact, homogeneous dark-brown argillites, and in East Estonia by argillites with thin interbeds of quartzose siltstone, anthraconite and pyrite nodules. The argillites are generally graptolitic but not in all sections and not in all their parts. The thickness of the formation is greatest in the western part of the area (up to $5 \mathrm{~m}$ ), but eastwards it decreases to $1.5 \mathrm{~m}$ at Kunda and thins out not far from Narva.

Koporye Formation. The lower part of the formation occurs only in the west of the Leningrad Region (Fig. 2). This division is represented by alternating fine-grained sandstones and siltstones and dark argillites (more rarely by brownish-grey slaty clays), with a considerable prevalence of sandstones and siltstones. The upper part of the formation, distributed from the Luga River to the Syas River, is composed of homogeneous dark graptolitic argillites containing anthraconite and pyrite nodules, in places also with siltstone interbeds.

The thickness of the Koporye Formation ranges from about $10 \mathrm{~cm}$ up to $5.4 \mathrm{~m}$.

Varangu Formation. Compact, mostly greenish-grey silty clays with interbeds of glauconite-bearing quartzose siltstone make up the Varangu Formation. In the clint sections, deposits occur sporadically with a maximum thickness (about $3 \mathrm{~m}$ ) near Kunda.

The $\mathrm{Naz}$ iy a Formation consists of greyish-green silty glauconitic clays, with thin interbeds of glauconitic-quartzose, fine-grained sandstones occurring at the base. The formation occurs in the area of the Naziya and Lava Rivers, with a maximum thickness of $0.4 \mathrm{~m}$.

\section{Biostratigraphy}

Paleontologically the boundary beds are not diverse. In the sandstones and siltstones inarticulate brachiopods are the most widely distributed fossil group; in the argillites (shales) graptolites predominate; conodonts and acritarchs occur in both rock types. Of the other fossil groups from the Obolus beds, hyolithelminthes have been recorded together with some other forms of uncertain systematic position. All those are of small correlative significance. Below we shall discuss more thoroughly the distribution of the inarticulate brachiopods, conodonts and graptolites (most of the species mentioned below are illustrated in Plates I-VI).

In articulate brachiopods. Recent investigations have shown that obolids may well be used for the subdivision and intraregional correlation of the East Baltic Cambro-Ordovician. However, the endemic character of this fauna and the inadequate state of study in many areas make it impossible to use them for wider correlation. The distribution of inarticulate brachiopods shows a clear lateral zonality which changes only a little throughout a rather long period: in the Middle and Late Cambrian the areas nearest to shore (mostly the areas of accumulation of fine- to medium-grained cross-bedded sands) were inhabited by the monotypic Obolus Community or in places the Ungula Community.* Seawards (mostly in the area of fine-grained sands) there

* The authors have made use of the nomenclature of inarticulate brachiopods in accordance with revision carried out by L. Popov. Reinvestigation of the types of E. Eichwald and topotypes of $\mathrm{Ch}$. Pander has revealed the independence of the genera Obolus and Ungula. Results of this work will be published separately. 
occurred communities of different species of the genus Oepikites, and later (beginning with the Proconodontus Zone) those of Schmidtites.

The offshore facies (mainly areas with silty deposits) were characterized by more varied communities consisting of acrotretids, siphonotretids (Schizambon) and obolids (Oepikites and Westonia?). At a level of the C. proavus Zone the brachiopod zonality becomes simpler and only two communities remain - a nearshore one with Obolus apollinis and a more offshore one with a siphonotretid (Helmersenia ladogensis) predominating.

At present at least four biostratigraphical levels are distinguished for the Late Cambrian and Early Ordovician of the clint area. Beds with Ungula inornata $(=$ Obolus triangularis Mickwitz $\neq$ Ungula triangularis Pander) and Angulotreta postapicalis are distinguished at the base of the Upper Cambrian (Ulgase Formation, lowermost beds of the Ladoga Formation). Beside the index species, the assemblage of inarticulate brachiopods of these beds also includes Oepikites sp. nov., Westonia? sp. nov., Schizambon sp. nov. and Ceratreta tanneri (Metzger).

Beds with Ungula convexa are distinguished within the upper part of the Ladoga Formation. In addition to the index species they have yielded «Ungula» ovata Pander, Oepikites sp. nov., Westonia ? sp. nov. and Keyserlingia reversa (Vern.); a little higher Keyserlingia buchii (Vern.) and Schmidtites celatus (Volborth) make their appearance. These beds may be correlated with the Westergaardodina moessebergensis-Problematoconites perforata Conodont Zone.

Beds with Ungula ingrica are distinguished in the lower part of the Kallavere Formation and its equivalents occurring in some places up to the Koporka River in the east. The assemblage of inarticulate brachiopods includes Ungula ingrica (Eichwald), Oepikites obtusus (Mickw.), Schmidtites celatus (Volborth), Keyserlingia buchii (Vern.) and Westonia ? sp. nov. These beds correspond with the Cordylodus andresi Zone and possibly partly with the C. proavus Zone.

Beds with Obolus apollinis and Helmersenia ladogensis are distinguished in the Tosna Formation and in the upper part of the Kallavere Formation. The assemblage of inarticulate brachiopods includes only Lingulella antiquissima (Jerem.) apart from the index species. The beds are correlated with the conodont zonation from the C. proavus Zone to the C. angulatus - C. rotundatus Zone (inclusive).

Conodonts occur in the East Baltic from the Upper Cambrian onwards. In the Upper Cambrian the Westergaardodina Zone has been defined conditionally and subdivided into three subzones (Table 1). The W. bicuspidata Subzone is the oldest and has been distinguished in the Olgase Formation and in the lower part of the Ladoga Formation, where in addition to the index species Phakelodus tenuis, Furnishina furnishi, F. alata and Prooneotodus terashimai have been identified. Conodonts of the two subsequent subzones were studied in the sections eastwards from Leningrad (Боровко и др., 1984; Боровко, Сергеева, 1981, 1985). The W. moessebergensis Subzone includes the index species plus W. cf. fossa, W. vimani, Hertzina americana, Problematoconites perforata, F. furnishi, Prooneotodus rotundatus and P. terashimai. The uppermost Proconodontus Subzone is characterized by the following assemblage: Proconodontus primitivus, Prooneotodus rotundatus, $P$. aff. gallatini, W. bicuspidata, W. fossa, F. furnishi and F. alata. An interval of the Turjekelder section has been assigned to the same subzone where below the first occurrence of $C$. andresi a similar assemblage has been recorded, but containing also Eoconodontus notchpeakensis (one speci- 
In higher beds, the Obolus Sandstone is characterized by various and in places numerous specimens of Cordylodus. The following succession of conodont zones has been established here (Table 1), in many aspects resembling the Australian sequence (Druce, Jones, 1971). The identified species of Cordylodus have been named according to multielement taxonomy, except $C$. prion, which was distinguished sensu formo, as it is useful for correlation in this sense.

The Cordylodus andresi Zone was established in four outcrops by the appearance of the zonal species. This taxon was first described by D. Andres (1981) on the basis of material from lenses of the «stink limestones of the Westergaardia Subzone of the Acerocare Zone on the Island of Oland, Sweden. The description of the East Baltic material is in print (Viira, Sergeyeva). C. andresi is characterized by a deep basal cavity, a lack of white matter and a variable number of denticles. Some specimens with a single small denticle are reminiscent of Cordylodus sp. 1 (Apollonov et al., 1984). However, it is difficult to say whether such specimens are marginal members of variations of this species or whether they represent a new species recorded by S. Dubinina below the beds with $C$. proavus in Kazakhstan. In this context it should be noted that $C$. andresi has not been found in Kazakhstan, but in the East Baltic it occurs at a level below the typical $C$. proavus. Apart from numerous specimens of the index species, the assemblage of the C. andresi Zone includes Phakelodus tenuis, Eoconodontus notchpeakensis and different paraconodonts (Westergaardodina, Furnishina, etc.), first appearing in the underlying beds. The full thickness of the interval (about $1.5 \mathrm{~m}$ ) is seen at Vihula.

The C. proavus Zone is of wider distribution, being recorded from six outcrops. Specimens of this species are morphologically rather variable and do not form large accumulations like $C$. andresi. In this assemblage, among others the most common species is E. notchpeakensis. The maximum thickness of the C. proavus Zone (over $8 \mathrm{~m}$ ) has been recorded in sandstones at Vihula.

Correlation of the C. proavus Zone has been discussed widely in recent literature (Miller, 1984; Chen et al., 1983; and others), and there is no reason to expand here these discussions further.

The C. intermedius Zone assemblage has been recorded from the Olgase, Toolse and Naziya sections. In the other studied sections this species appears together with $C$. lindstromi, i. e. the index species of the following zone. At the three outcrops, the C. intermedius Zone occupies a short interval in the Obolus Sandstone, with a maximum thickness of up to $1 \mathrm{~m}$ at Toolse; the assemblage includes $C$. proavus and E. notchpeakensis. Despite unsatisfactory characteristics of this zone, we distinguish it here for purposes of correlation. The $\mathrm{C}$. intermedius Zone has also been established in North China between the C. proavus and C. angulatus Zones (Chen et al., 1983). In Australia, C. intermedius defines the lower boundary of the C. oklahomensis-C. lindstromi Zone (Druce, Jones, 1971); in North America it appears in the Hirsutodontus simplex Subzone of the C. proavus Zone (Miller et al., 1982).

The C. lindstromi Zone has been established in all the studied sections, with a maximum thickness $(1.60 \mathrm{~m})$ at Toolse. Besides the index species, the zonal assemblage contains $C$ proavus, C. aff. proavus (Syas), $C$. drucei, $C$. prion. In this zone E. notchpeakensis is replaced by Oneotodus altus, the species which J. Miller (1980) includes within the multispecies E. notchpeakensis. Until the description of East Baltic conodonts is completed, we consider it expedient to retain the taxon $O$. altus separately. The C, lindstromi Zone has been established in Australia (Druce, 
Jones, 1971), and in Kazakhstan (Дубинина, 1982), but the species is also known in North America from Fauna B (Miller et al., 1982).

The $\mathrm{C}$. rotundatus - C. angulatus Zone has been recorded from all the studied sections and is defined by the first appearance of $C$. rotundatus. It is characterized by the presence of a considerable number of different species: rare $C$. proavus co-occur with $C$. lindstromi, $C$. intermedius, C. drucei, C. prion, Iapetognathus sp. and Oneotodus altus. Simple conical Acodus firmus and Drepanodus ? sp., considered to characterize the Ceratopyge Stage (Upper Tremadoc), make their first appearance at this level.

Graptolites. Since the papers of E. Eichwald in the 19th century, North East Baltic Dictyonema has been of considerable interest for researchers. In this paper we do not deal with taxonomic problems, and therefore we make use of the most commonly accepted nomenclature of O. M. B. Bulman (1954), leaving aside the views of A. M. Obut (Обут, 1953) regarding the species groups flabelliforme and graptolithinum, as well as those of B.-D. Erdtmann (1982) concerning Rhabdinopora, although some of us support the various ideas presented by these authors.

Graptolites occur throughout the whole section of the Pakerort and Ceratopyge Regional Stages of the East Baltic Tremadoc. The most common are those in Dictyonema Shale, but they are also fairly abundant in clay interbeds within sandstones, but only rare finds come from the sandstones themselves. The oldest specimens of Dictyonema sp. (fragments only) have been recorded from the Upper Cambrian Ulgase Formation (collected by K. Khazanovich from Maardu).

The distribution of Tremadoc graptolites has been discussed by D. Kaljo and E. Kivimägi (Кальо, Кивимяги, 1970, 1976) and the corresponding zonation is given in Table 1. The sections treated in this paper have yielded scarce graptolites (Fig. 3), but they enable correlations to be made between the graptolite and conodont zones. A generalized distribution of the identified graptolite species given in Table 2 was composed on the basis of their relations with conodont zones. As graptolites and conodonts have been studied together only in a small number of sections, the mutual position of zonal boundaries drawn from these groups (Table 1) must be considered tentative.

Especially insufficiently founded is the position of the D. f. sociale Zone, whose presence has been established in a number of sections in the lowermost beds of the Pakerort Regional Stage (vicinity of Tallinn, Orasoja, and elsewhere). Of these sections, conodonts have been studied only in the outcrop of Suhkrumägi. $D$. $f$. sociale was identified from a shale intercalation below the Detritus Bed in the Hundikuristik Section. The latter is situated less than one kilometre south of the Suhkrumägi outcrop. Together with the other subspecies, D. flabelliforme flabelliforme occurs throughout the whole section of the Pakerort Regional Stage. Therefore it has not been indicated specially in Fig. 3.

\section{PLATE I}

1-3. Ungula ingrica (Eichwald); $I$ - outer view of the ventral valve, B 1701, X3.2; 2 - inner view of the ventral valve, B $1700, \mathrm{X} 3.2 ; 3$ - inner view of the dorsal valve, B 1702, X3.2; Turjekelder section, C. andresi Zone; 4-7. Obolus apollinis Eichwald; 4 - outer view of the ventral valve, B 1705 , X3.2; 5 - inner view of the ventral valve, B 1703, X3.2; 6 - inner view of the dorsal valve, B 1706, X3.2; 7 - outer view of the dorsal valve, B 1704, X3.2; section along the Lava River, Tosna Formation. 8, 9. Helmersenia ladogensis (Yeremeyev); 8 - outer view of the dorsal valve, B $1707, \mathrm{X} 8 ; 9$ - outer view of the ventral valve, B 1708, X20; Volkhov River, 


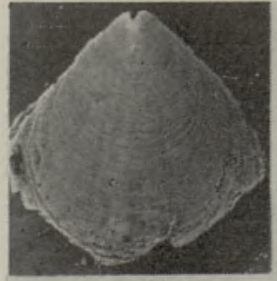

1

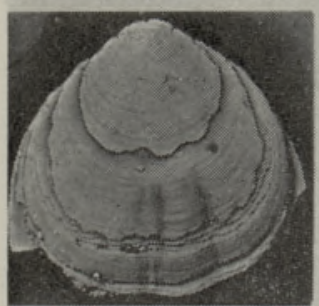

4

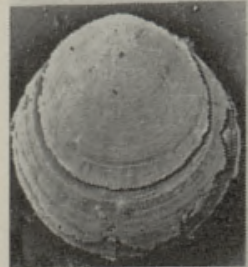

7
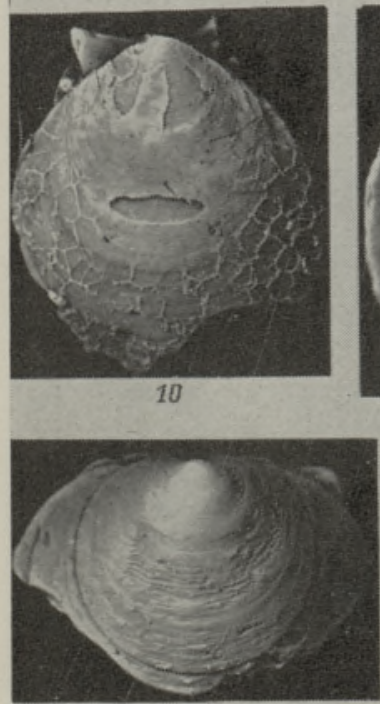

13

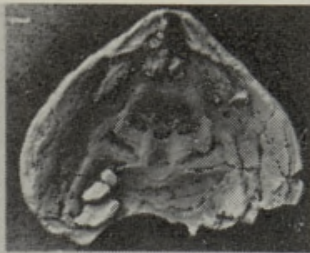

2

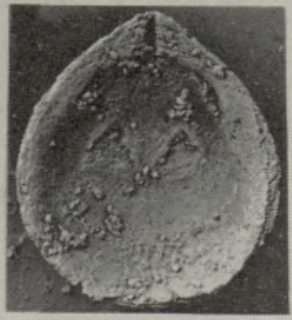

5

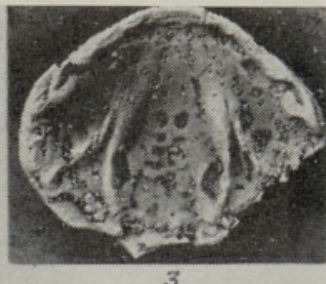

3

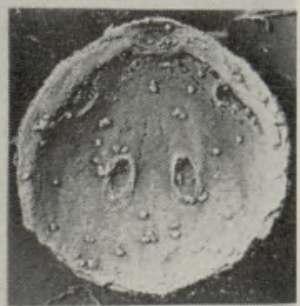

6

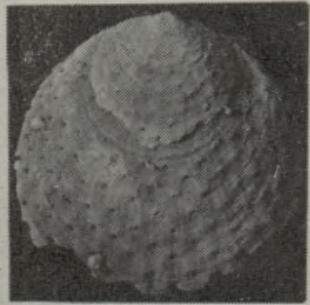

8
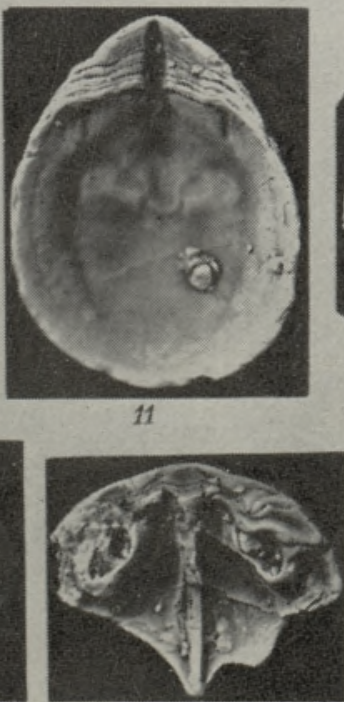

14

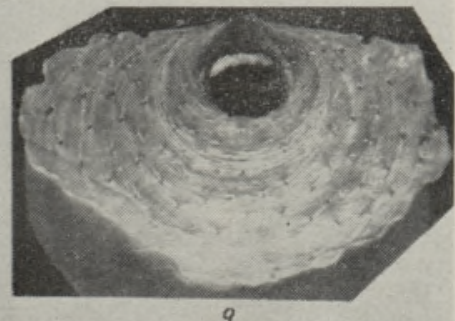

9
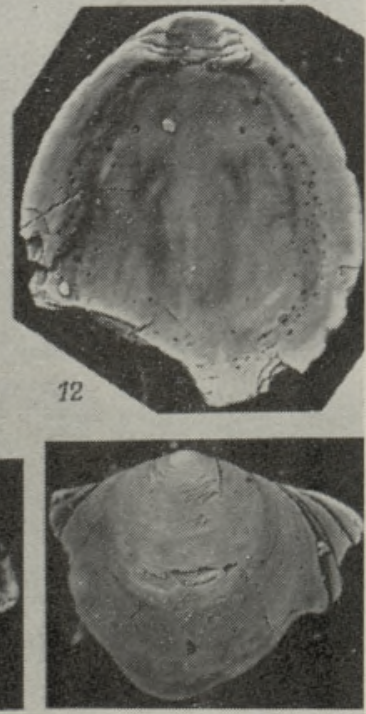

15

Tosna Formation, C. proavus Subzone. 10. Marcusodictyon priscum Bassler on the ventral valve of Schmidtites celatus (Volborth), B 1711, X6.4; Turjekelder section, C. andresi Zone. 11, 12. Schmidtites celatus (Volborth); 11 - inner view of the ventral valve, B 1709, X6.4; 12 - inner view of the dorsal valve, B 1710, X6.4; Turjekelder section, C. andresi Zone. 13-15. Keyserlingia buchii (de Verneuil): 13 outer view of the ventral valve, B $1712 ; 14$ - inner view of the dorsal valve, B 1714, X6.4; 15 - outer view of the dorsal valve, B 1713, X6.4; Turjekelder section, C. andresi Zone. 

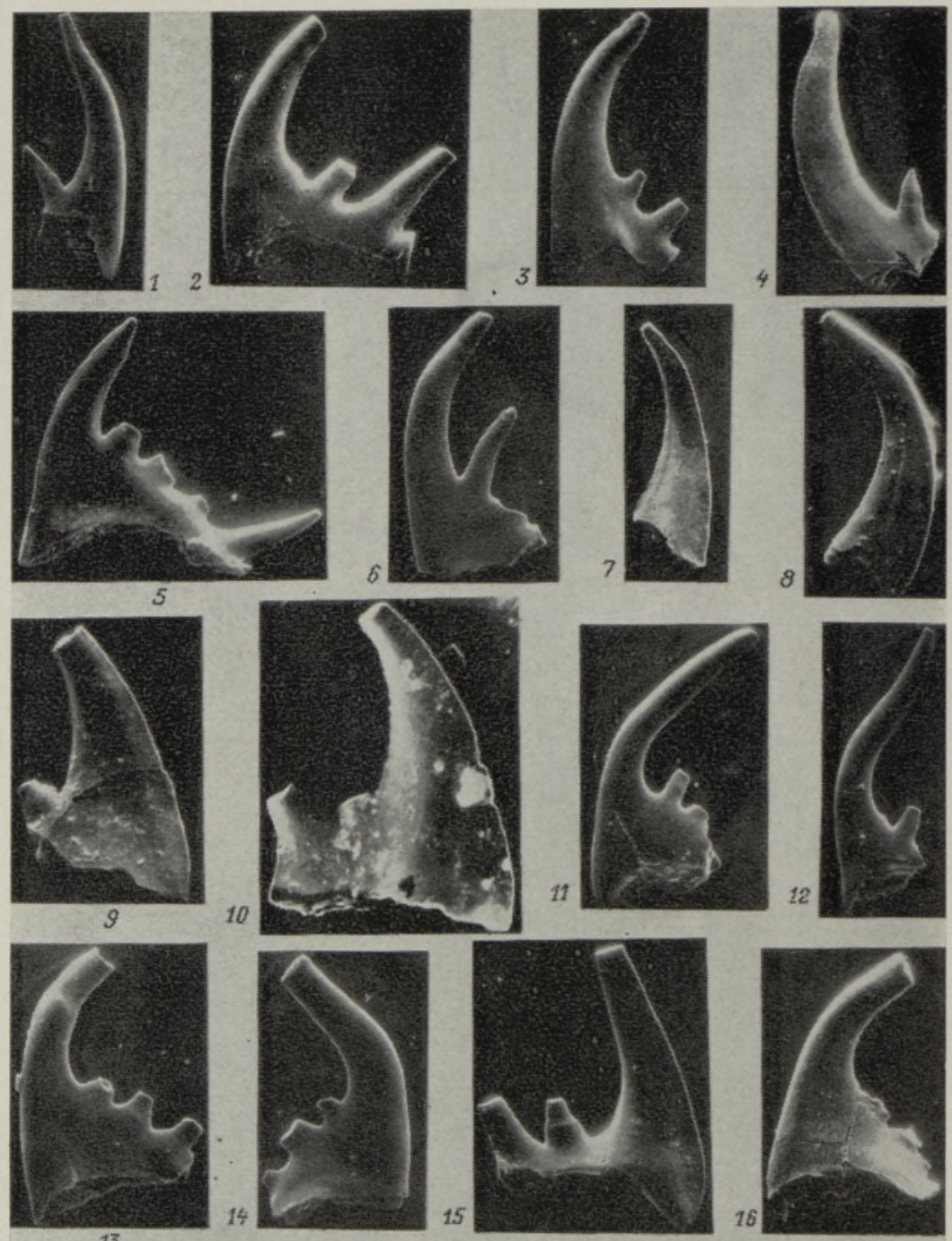

13

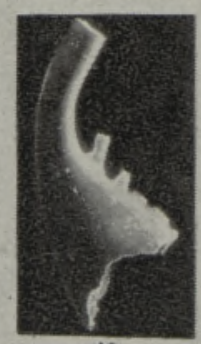

18

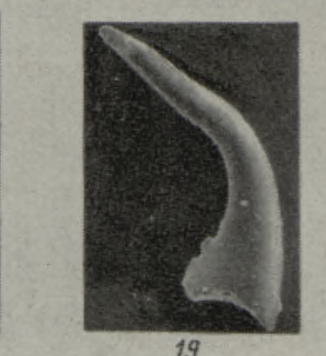

19
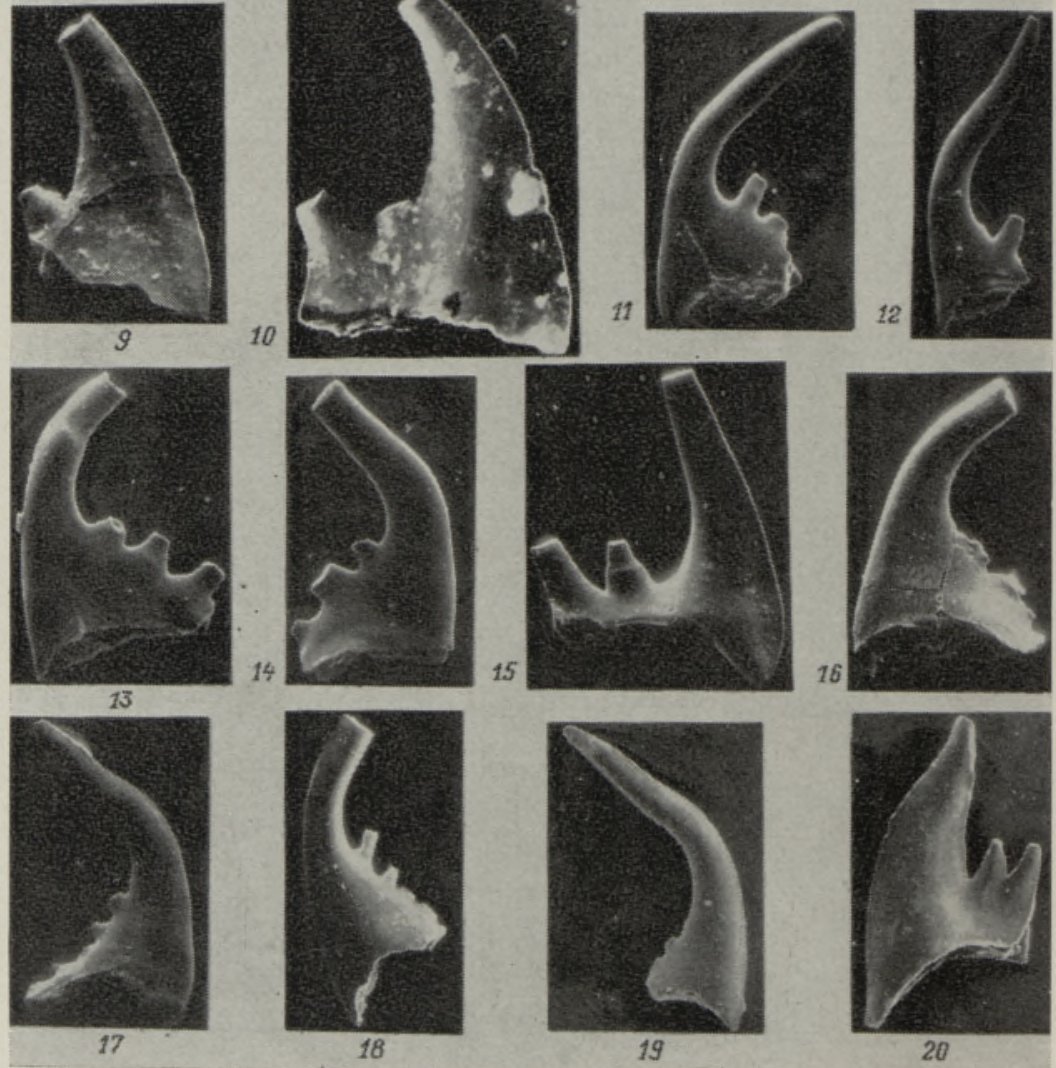

All conodont magnifications are $\times 55$.

1-6, 9, 10. Cordylodus andresi sp. nov. (Viira, Sergeyeva, in print): 1-3, $5,9-\mathrm{Cn} 1032-1036$, Vihula; 4, 6-Cn 1037, 1038, Toolse, Kallavere Formation; $10-\mathrm{Cn}$ 1039, Lomashka, Lomashka Formation, 7, 8. Eoconodontus notchpeakensis (Miller): Cn 1040, 1041, Vihula, Kallavere Formation. 11-20. Cordylodus proavus Müller: 11-15 - Cn 1042-1046, Vihula; 16, 17, - Cn 1047, 1048,

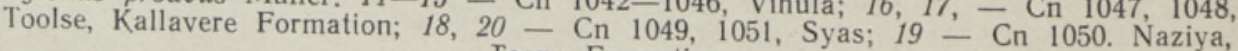
Tosna Formation. 

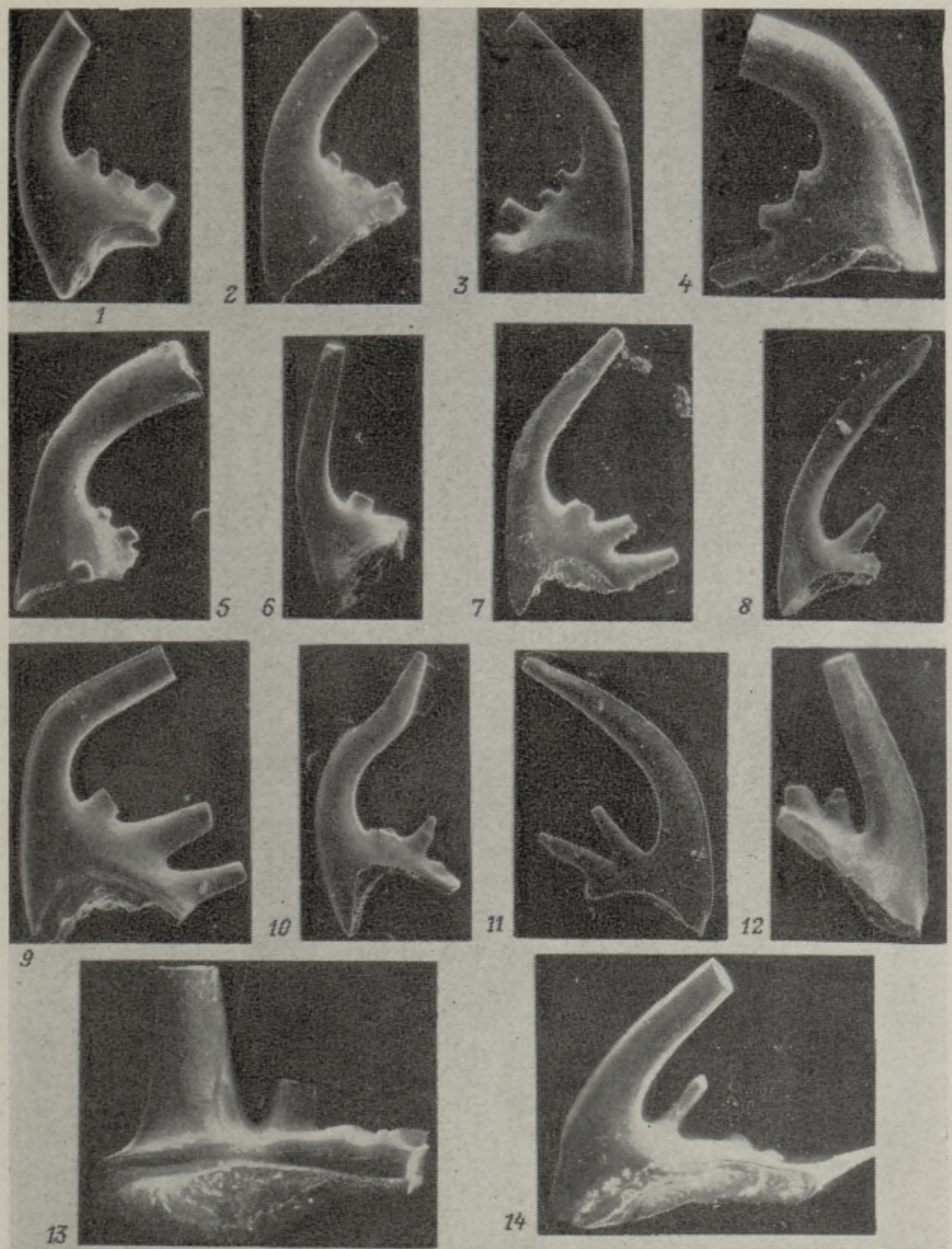

n
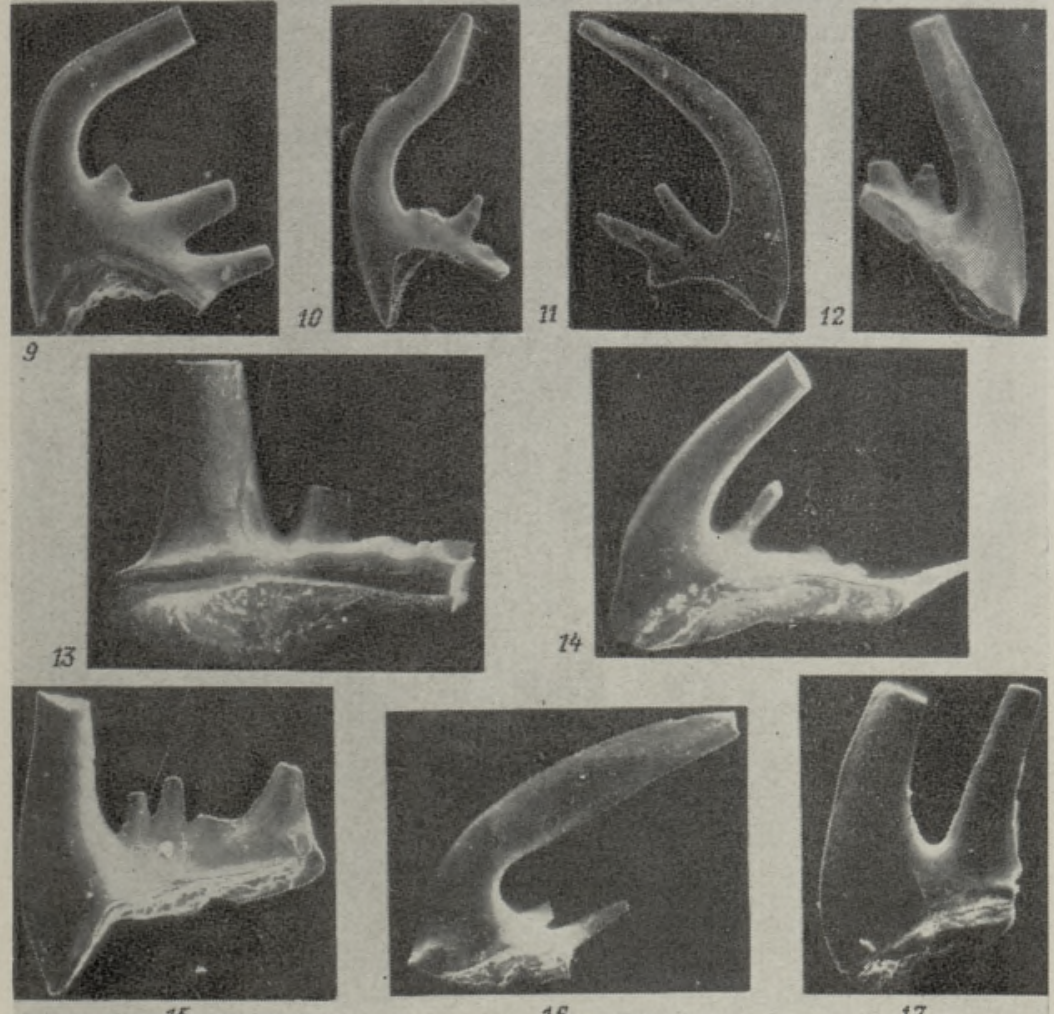

16

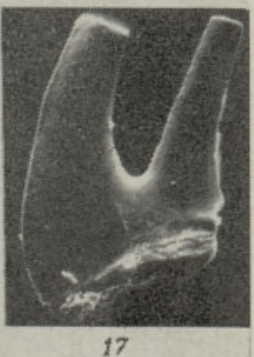

1. Cordylodus proavus Müller: Cn 1052, Toolse, Kallavere Formation. 2-6. Cordylodus intermedius Furnish: Cn 1053-1057, Toolse,-Kallavere Formation. 7-11. Cordylodus lindstromi Druce et Jones: Cn 1058-1060, Toolse, Kallavere Formation, $10,11-$ Cn 1061-Cn 1062, Naziya, Tosna Formation. 12, 14, 16. Coidylodus drucei Miller: 12Cn 1063, Tooise, 14, 16 - Cn 1065, 1066, Turjekelder, Kallavere Formation. 13 - Iapetognathus sp.: $\mathrm{Cn}_{\mathrm{n}}$ 1064, Turjekelder, Kallavere Formation. 15. Cordylodus prion Lindström: Cn 1067, Syas, Tosna Formation. 17. Cordylodus sp.: Cn 1068, Vihula, Kallavere Formation. 


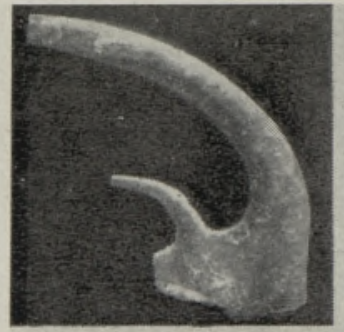

1

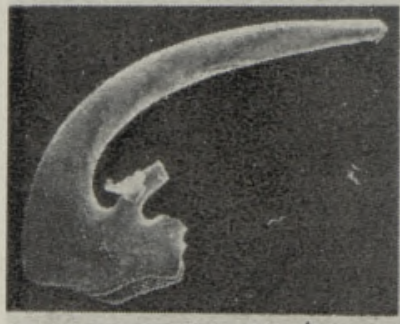

4

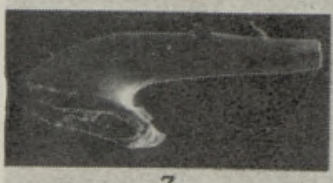

7

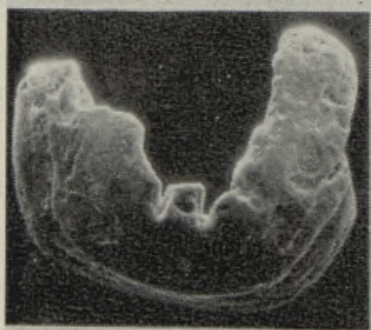

8

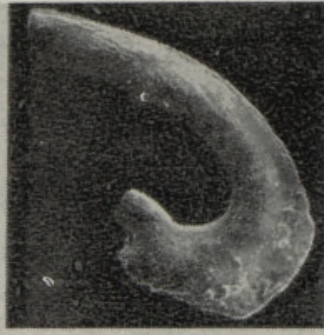

2

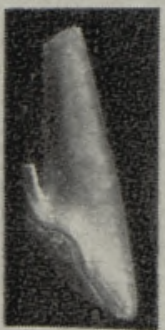

5

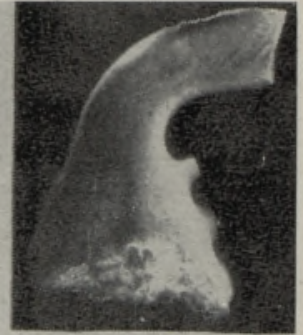

3

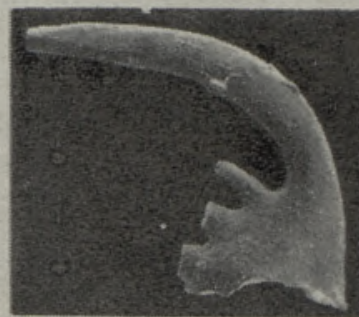

6

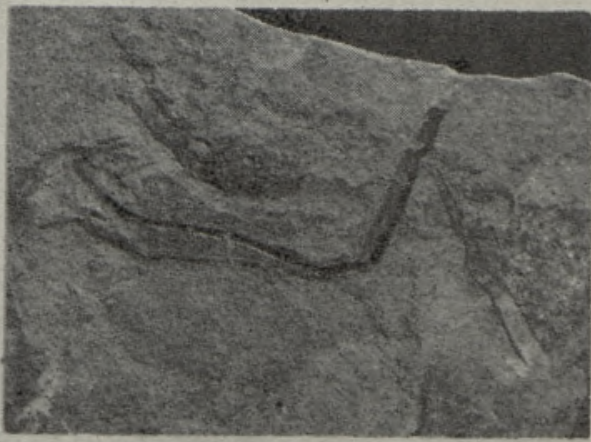

10

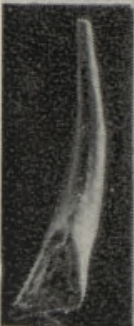

9

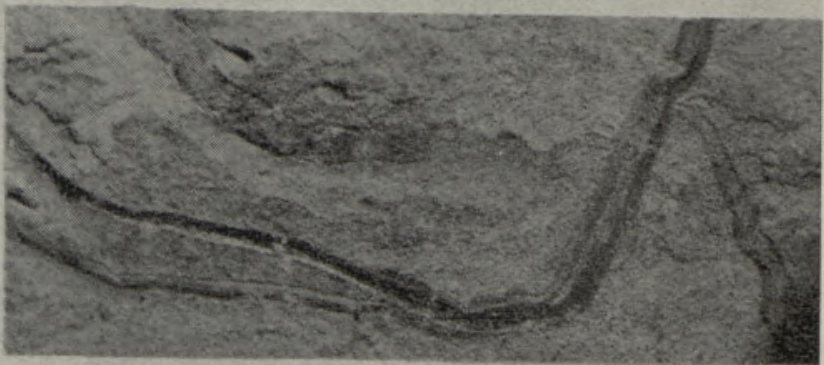

11

1, 4, 6. Cordylodus angulatus Pander: Cn 1069-1071, Suhkrumägi, Kallavere Formation. 2. Cordylodus rotundatus Pander: Cn 1072, Ulgase, Kallavere Formation. 3. Cordylodus angulatus cf. C. intermedius Furnish: $\mathrm{Cn} 1073$, Turjekelder, Kallavere Formation. 5. Cordylodus prion Lindström: Cn 1074, Toolse, Kallavere Formation. dina cf, moessebergen Miller: $\mathrm{Cn} 1075$, Toolse, Kallavere Formation. 8. Westergaardosp.: Cn 1077, Toolse, Kallavere Form 1076, Toolse, Kallavere Formation. 9. Cordylodus in situ, $\mathrm{C}$. Torellella sp.: 10 - three specimens X4; section along the Toolse River, base of the C. andresi Subzone. 

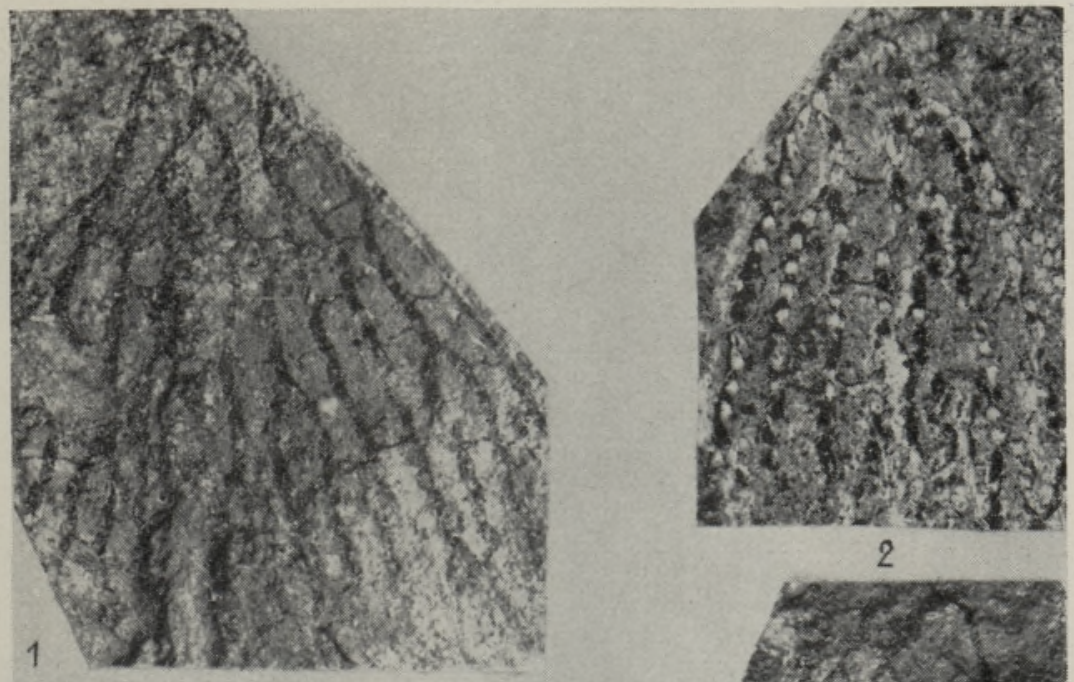

\section{2}
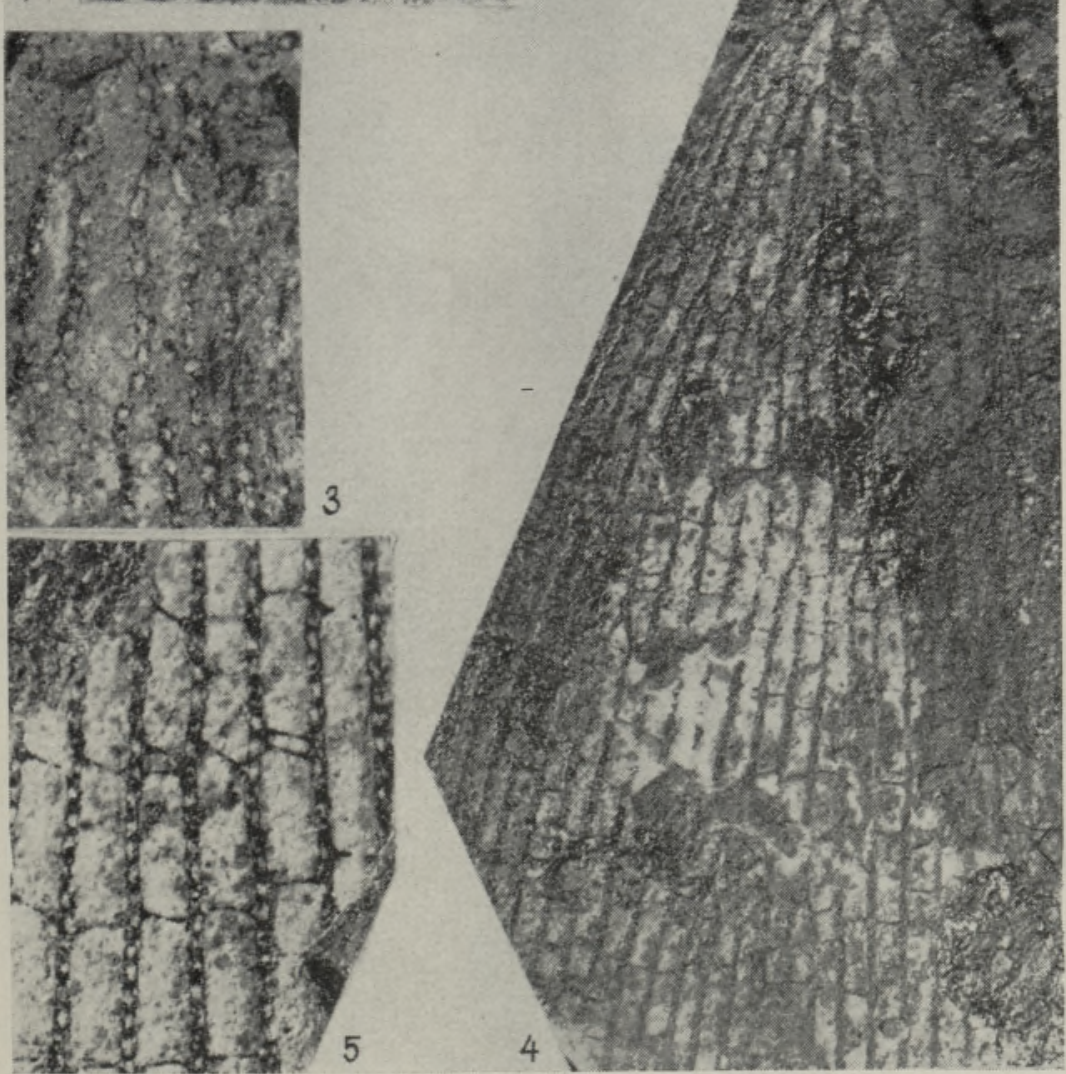

1. Dictyonema flabelliforme cf. anglicum Bulman, Va 1024, Naziya, Tosna Formation. 2. 3. Dictyonema flabelliforme aff. bryograptoides Bulman: 2 - Va 1025; 3 - Va 1026, Naziya, Tosna Formation. 4, 5. Dictyonema flabelliforme flabelliforme (Eichw.): Va 1027, 1028, Syas, Koporye Formation. 2-X4.3; $4-\mathrm{X} 2$, others - X4. 

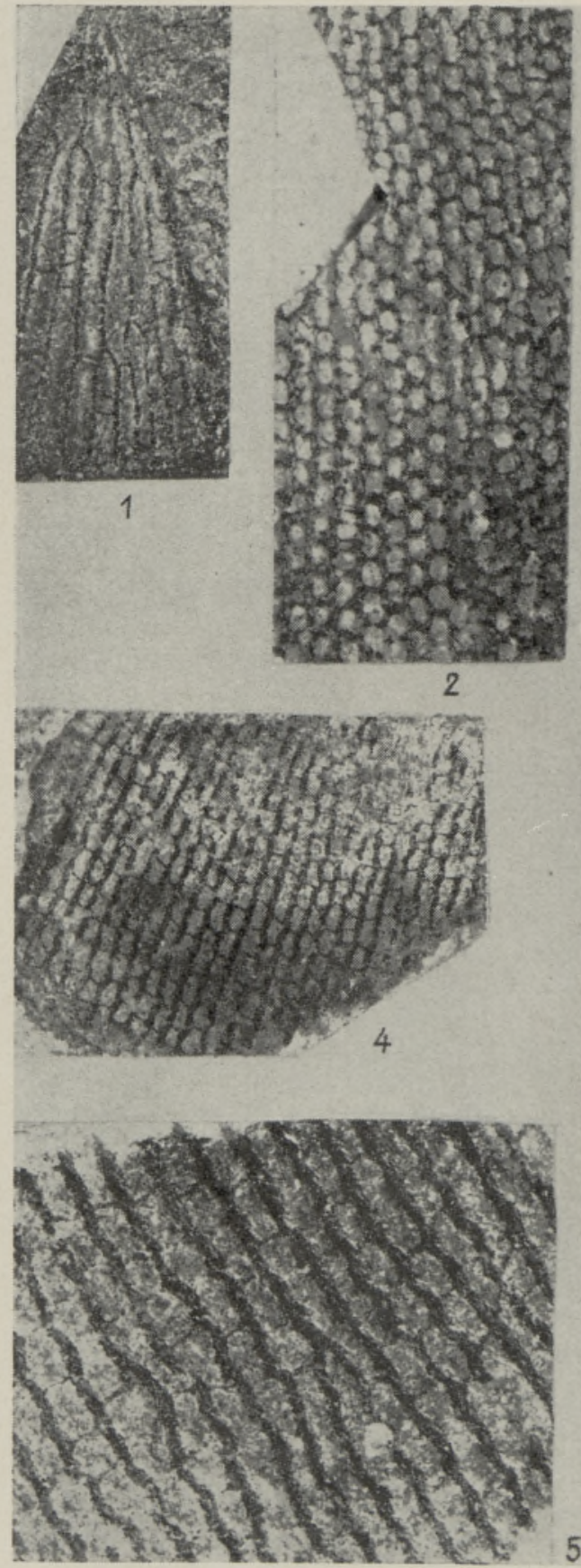

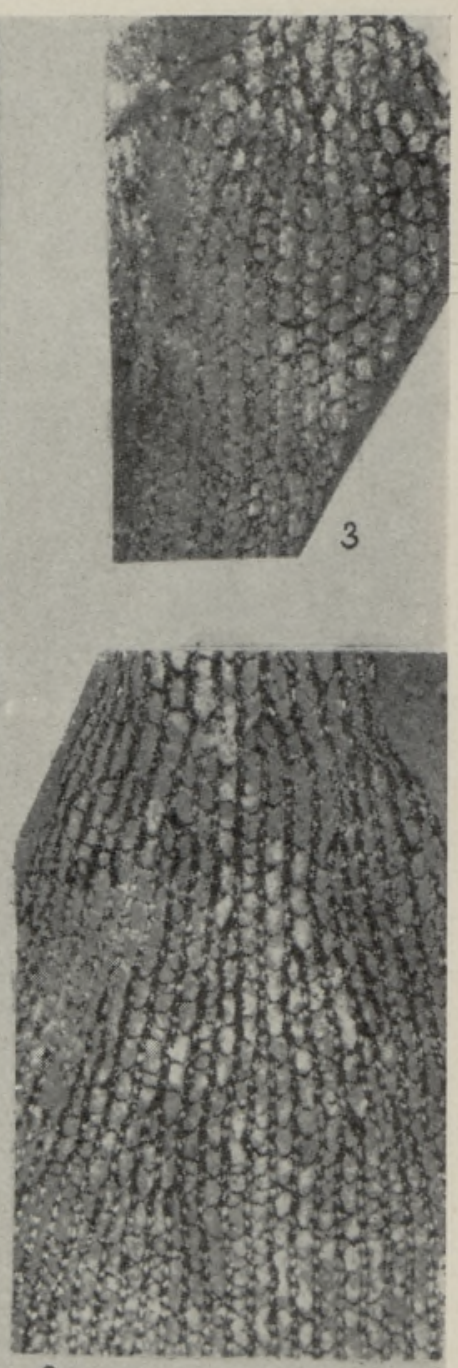

6

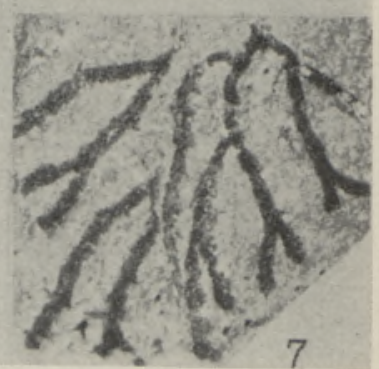

1. Dictyonema flabelliforme aft. multithecatum Bulman, Va 1029, Viruküla boring, Türisalu Formation. 2, 3. Dictyonema flabelliforme norvegicum (Kjerulf): 2 - Va 1030, $\mathrm{X} 2,5 ; 3,-\mathrm{Va} 1031$, X2,7, Risti boring, depth $183 \mathrm{~m}$, Türisalu Formation. 4, 5, Dictyonema flabelliforme rossicum Obut; $4-\mathrm{Va} 1032$, X2,6; $5-\mathrm{Va} 1033$, X5. Syas, Koporye Formation. 6. Dictyonema flabelliforme sociale (Salter): Va 1034, X2,5, Pōōsaspea boring, depth $38.8 \mathrm{~m}$, Türisalu Formation. 7. Anisograptus sp.: Va 1035, X5, Syas River, Koporye Formation. 


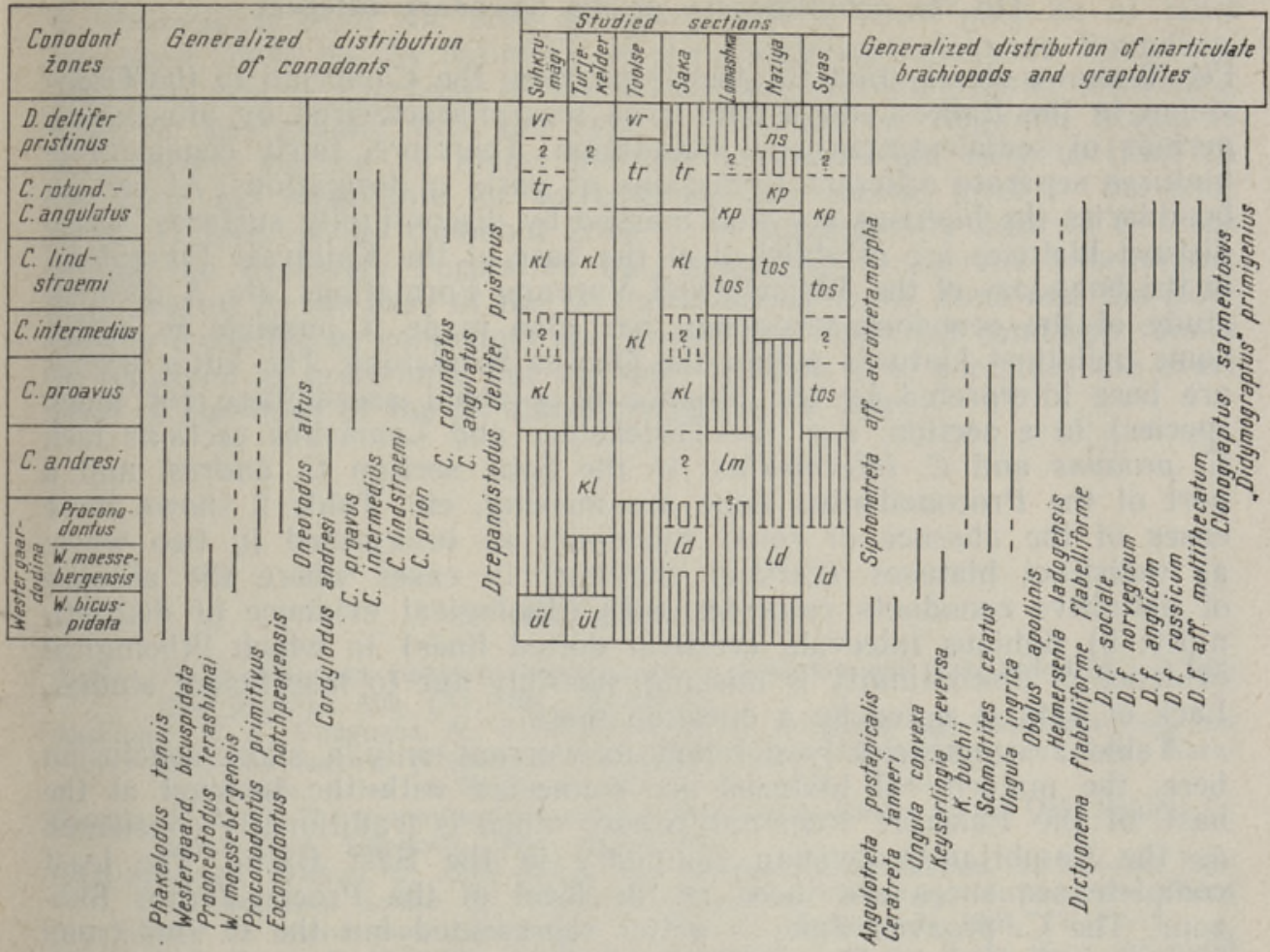

Table 2.

The available material allows us to conclude, though somewhat tentatively, that the group of $D$. flabelliforme appeared in the East Baltic not later than the C. intermedius Zone, but at present we cannot prove it for the upper part of the Cordylodus proavus Zone.

Graptolites are most common at the level of the C. lindstromi and C. rotundatus - C. angulatus Conodont Zones. In the Pakerort Regional Stage the most abundant subspecies beside $D$. $f$. flabelliforme are $D$. $f$. aff. multithecatum and D. f. rossicum; in the west $D$. $f$. norvegicum also occurs.

It should be noted that a number of transitional forms occur between the typical $D$. f. flabelliforme on one side and $D$. $f$. anglicum and $D$ f. multithecatum on the other side within the upper part of the Pakerort Regional Stage. A revision of the type material of D. rossicum described by A. M. Obut (Обут, 1953) (housed at Leningrad State University) enables us to consider it a distinct subspecies of the $D$. flabelliforme group, and to reveal its wide distribution at the level shown (Fig. 3). In its undulating branches, oval meshes and more or less regularly placed dissepiments $D$. $f$. rossicum is undoubtedly similar to $D$. $f$. norvegicum, but differs clearly from the latter in its fine dissepiments.

In the Ceratopyge Regional Stage (Clonograptus - Didymograptus Zone) the composition of the assemblage changes completely. Dictyonema is replaced by Clonograptus and Didymograptus together with Adelograptus, Bryograptus and Kiaerograptus. The latter was found recently in the Türisalu Formation in the sections south of Tallinn. 


\section{On the completeness of the boundary interval}

Fig. 2 shows clearly that the transition from the Cambrian to the Ordovician in the Baltic-Ladoga clint area was characterized by alternating periods of sedimentation and denudation. Therefore, fairly considerable hiatuses separate different formations or parts of formations. At certain boundaries the hiatuses are well marked by discontinuity surfaces. These distinct hiatuses are established at the base of the Kallavere Formation, at the boundary of the Türisalu and Varangu Formations, etc. A detailed study of the conodont succession has also made it possible to detect some indistinct hiatuses within the Obolus Sandstone. The latter breaks are here interpreted by the absence of a zonal assemblage (or index species) in a section, e.g. the Turjekelder and Lomashka sections lack $C$. proavus and $C$. intermedius; in the Syas section $C$. andresi and a part of the Proconodontus Zone are missing, etc. Table 2 shows these cases of the absence of zonal conodonts as interpreted in two ways: a) indistinct hiatuses (vertical shading) in cases where the absence of definitive conodonts coincides with lithological evidence of discontinuity; b) dubious intervals (vertical dotted lines) in which lithological evidence of discontinuity is missing, possibly due to insufficient studies. Lack of data is noted by a question mark.

Table 2 is sufficiently detailed to warrant only a short conclusion here: the majority of hiatuses are connected with the interval at the base of the Pakerort Regional Stage, which is traditionally considered as the Cambrian-Ordovician Boundary in the East Baltic. The least complete sequences are those at the level of the Proconodontus Subzone. The C. proavus Zone is better represented but the $\mathrm{C}$. lindstromi and $C$. rotundatus - C. angulatus Zones evidently correspond to the transgression maximum of the earliest Ordovician sea in the East Baltic. The transgression started somewhat earlier, but in general its level coincides with the Black Mountain eustatic event as described by J. Miller (1984).

\section{Conclusions}

1. Despite the shallow-water character of the sandstones at the Cambrian-Ordovician Boundary interval, and the several local and regional hiatuses in the sections (most importantly those at the level of the Proconodontus Subzone), we are able to establish a relatively complete sequence of conodont, graptolite and also brachiopod zones.

2. Co-occurrence of the named fossil groups have made it possible to correlate conodont and graptolite zonations.

The relations of the lowest graptolite and conodont zones are not very well documented, so that with certainty we can only conclude that the Dictyonema ( = Rhabdinopora) flabelliforme group appears not later than the Cordylodus intermedius Zone. At the level of the $\mathrm{C}$. andresi Zone we have found no graptolites, but we cannot exclude the possibility that the D. f. sociale Subzone may be correlated, at least partly, with the C. proavus Zone.

A correlation of the D. norvegicum and D. anglicum-multithecatum -rossicum Subzones with the Cordylodus lindstromi and partly C. intermedius Zones is well documented.

The lower boundary of the C. rotundatus-angulatus Zone falls within the D. anglicum-multithecatum-rossicum Subzone.

3. East Baltic sections provide interesting data for discussion of the Cambrian-Ordovician Boundary, but none of them can be recommended for use as a stratotype section. 
4. Proceeding from the data presented above, there may be at least two good levels for the definition of the Cambrian-Ordovician Boundary. The first one - the base of the $\mathrm{C}$. andresi conodont Zone, coinciding more or less exactly with the base of the Pakerort Regional Stage, is a boundary marked by major hiatuses and therefore easy to trace in the field, but unsuitable for correlations. The second level - the base of the C. intermedius conodont Zone - is lithologically difficult to trace within the Kallavere Formation but, according to current information, it is nearest to the base of the D. flabelliforme (s. 1.) Zone and therefore readily traceable by conodonts and graptolites. This last condition should be regarded as preferable, but the only problem is to ascertain the exact level of the base of the D. flabelliforme (s. 1.) Zone.

\section{REFERENCES}

Andres, D. Beziehungen zwischen kambrischen Conodonten und Euconodonten. - Berliner geowiss. Abh. (A), 1981, 32, 19-31.

Apollonov, M. K., Chugaeva, M. N., Dubinina, S. V. Trilobites and conodonts from the Batyrbay section (Uppermost Cambrian - Lower Ordovician) in Malyi Karatau Range. Atlas of Paleontol. Plates. Alma-Ata, 1984.

Bulman, O. M. B. The graptolite fauna of the Dictyonema Shales of the Oslo Region. Norsk Geol. Tidsskrift, 1954, 33, 1-40.

Chen Jun-ynan, Teichert, C., Zhou Zhi-yi, Lin Yao-kun, Wang Zhi-hao, Xu Jun-tao. Faunal sequence across the Cambrian-Ordovician boundary in Northern China and its international correlation. - Geol. et Palaeontol., 1983, 17, 1-15.

Druce, E. C., Jones, P. J. Cambro-Ordovician conodonts from the Burke River structural belt, Queensland. - Australia Bur. Min. Res., Geol., Geophys., 1971, Bull. 110, 158.

Erdtmann, B.-D. A reorganization and proposed phylogenetic classification of planktic Tremadoc (Early Ordovician) dendroid graptolites. - Norsk Geol. Tidsskrift, $1982,62,121-145$.

Miller, J. F. Taxonomic revision of some Upper Cambrian and Lower Ordovician conodonts with comments on their evolution. - Univ. Kansas Paleontol. Contrib., 1980, Paper 99, 44.

Miller, J. F. Cambrian and earliest Ordovician conodont eovlution, biofacies, and provincialism. - Geol. Soc. Amer., Spec. Paper, 1984, 196, 43-68.

Miller, J. F., Taylor, M. E., Stitt, J. H., Ethington, R. L., Hintze, L. F., Taylor, J. F. Potential Cambrian-Ordovician boundary stratotype sections in the western United States. - In: The Cambrian - Ordovician Boundary: Sections, Fossil Distributions and Correlations. Nat. Mus. Wales, Geol. Ser, 1982, N 3, $155-180$.

Öpik, A. Kambrium, Ordovicium, Gotlandium. - In: Bubnoff, S. Fennosarmatia. Die Sarmatische Tafel. Berlin, 1952, 119-134.

Боровко Н. Г., Сергеева С. П. Конодонты позднего кембрня и раннего ордовика бассейна р. Ижоры. - Докл. АН СССР, 1981, 261, 149-151.

Боровко Н. Г., Сергеева С. П., Волкова Н. А., Голуб Н. Н., Горянский В. Ю., Попов Л. Е., Хазанович К. К. Опорный разрез пограничных отложений кембрия и ордовика Северо-Запада Русской плиты (р. Ижора). - Изв. АН СССР. Сер. геол., 1984, № 7, 54-63.

Боровко Н. Г., Сергеева С. П. Конодонты верхнекембрнйских отложений БалтийскоЛадожского глинта. - Изв. АН ЭССР. Геол., 1985, 34, № 4, 125-129.

Волкова Н. А. Акритархи среднего и верхнего кембрия Московской синеклизы. Изв. АН СССР. Сер. геол., 1980, № 12, 40-57.

Волкова Н. А. О возрасте юльтазеской пачки на границе кембрия и ордовика в Эстонни. - Сов. геол., 1982, № 9, 85-88.

Дубинина С. В. Конодонтовые ассоциации пограничных отложений кембрия и ордовика Малого Каратау (Южный Казахстан). - Изв. АН СССР. Сер. геол., 1982, № $4,47-54$.

Кальо Д., Кивимяги Э. О распределении граптолитов в диктионемовом сланце Эстонии и разновозрастности его фаций. - Изв. АН ЭССР. Хим. Геол., 1970, 19, № 4, 334-341.

Кальо Д. Л., Кивимяги Э. К. Зональное расчлененне тремадока Эстонни. - В кн.: Граптолиты и стратиграфия. Таллин, 1976, 56-63. 
Менс К. А., Пиррус Э. А. Стратотипические разрезы кембрия Эстонии. Таллин, 1977.

Обут А. М. Дендроидеи северо-запада Русской платформы. - Тр. Всес. нефт. научноиссл. геол.-разв. ин-та, нов. сер., 1953, вып. $78,26-57$.

Хазанович К. К., Попов Л. Е. Мельникова Л. М. Беззамковые брахиоподы, остракоды (брадоринды) и хиолительминты из саблинской свиты Ленинградской обл. - Палеонт. ж., 1984, № 4, 33-47.

Academy of Sciences of the Estonian SSR,

Received Institute of Geology

Feb. 6, 1986

All-Union Geological Research Institute

State Mineral-Chemical Raw Material

Research Institute

Leningrad Pedagogical Institute

All-Union Research Institute Okeangeologia

D. KALJO, Nelli BOROVKO, Heljo HEINSALU, K. HAZANOVITS, Kaisa MENS, L. POPOV, S. SERGEJEVA, R. SOBOLEVSKAJA, Viive VIIRA

\section{KAMBRIUMI JA ORDOVIITSIUMI PIIR BALTI-LAADOGA KLINDI PIIRKONNAS (POHJA-EESTI JA LENINGRADI OBLAST, NSV LIIT)}

Seitsme läbilōike detailse uurimise (vt. litolooga ja fossiilide levik joonisel 3) ja muu materjali alusel väidetakse, et Dictyonema flabelliforme tsoon (s. 1.) algab mitte hiljem kui Cordylodus intermedius'e tase. Selle tsooni algus on üks sobivaid kambriumi ja ordoviitsiumi piiri tasemeid. Teine vōimalus on traditsiooniline Pakerordi lademe (Kallavere kihistu) algus (Cordylodus andres'i tsooni algus), mis litoloogiliselt on selgem (alla jääb ka ulatuslikum settelünk), kuid kaugem graptoliitidega määratletud piirist.

Д. КАЛЬО, Нелли БОРОВКО, Хельо ХЕННСАЛУ, К. ХАЗАНОВНЧ, Кайса МЕНС,

Л. ПОПОВ, С. СЕРГЕЕВА, Р. СОБОЛЕВСКАЯ, Вийве ВИИРА

\section{ГРАНИЦА КЕМБРИЯ И ОРДОВИКА В РАИОНЕ БАЛТИИСКО-ЛАДОЖСКОГО ГЛИНТА (СЕВЕРНАЯ ЭСТОНИЯ И ЛЕНИНГРАДСКАЯ ОБЛАСТЬ, СССР)}

На основе детального изучения семи разрезов (литологию и распространение фоссилий см. рис. 3) и других материалов утверждается, что зона Dictyonema flabelliforme (s. 1.) начинается не позже уровня зоны Cordylodus intermedius. Начало этой зоны один из возможных уровней проведения границы кембрия и ордовика. Вторая возможность - традиционная подошва пакерортского горизонта (каллавереской свиты) на уровне подошвы зоны Cordylodu's andresi. Литологически она более четко выражена (ниже установлен наиболее существенный перерыв осадконакопления), но находится дальше от определенной по граптолитам границы. 